Vol 1 No 1 Desember 2019

ARTIKEL PENELITIAN

\title{
PENGARUH PEMBERIAN JINTAN HITAM (NIGELLA SATIVA) TERHADAP KETERKENDALIAN GLIKEMIK PADA PASIEN DIABETES TIPE 2 DI RUMAH SAKIT UMUM DELI SERDANG
}

\author{
Deby Maharani ${ }^{1}$, Lita Septina Chaniago ${ }^{2}$ \\ ${ }^{1}$ Fakultas Kedokteran, Universitas Muhammadiyah Sumatera Utara \\ ${ }^{2}$ Departemen Ilmu Penyakit Dalam,Universitas Muhammadiyah Sumatera Utara \\ Email: debymaharani14@gmail.com
}

\begin{abstract}
Diabetes melitus type 2 is one of disease that frequently happen and the prevalensi rate in a society tend to increase and this is an annual disease for the rest of our life. The purpose of this research is to find out the effect of glicemic in addition of black cumin oil to HbAlc (\%) diabetes melitus type 2's content. This research is an experimental research with pretest post test control group design. The subject in this research is diabetes melitus patient type 2 in Deli Serdang Region Hospital based on the inclution and exclution criteria in October 2018 with total of 22 person which grouped into standart and control group. Each group $(n=11)$ had been checked for their HbAlc (\%) at the beginning and at the end research for 8 weeks. In control group's patients had been given 500mg black cumin oil once a day as the addition of metformin. This research technique using purposive sampling and analyzing the data with paired sample t test with normality test using Shapiro-Wilk test. The result from this research that is we can see the HbAlc (\%) average (last inspection) on patient with treatment $(8,0889)$ is lower than the average HbAlc (last inspection) on patient without treatment $(8,4778)$. The result paired sample t test $P$ value $=0,017$. There is a significant derivation with the diabetes melitus type 2 patients that had been treat with black cumin oil.
\end{abstract}

Keywords: Black cumin oil, Diabetes, Poor glycemic control, Glycated hemoglobin (HbAlC)

\section{PENDAHULUAN}

Diabetes Mellitus (DM) merupakan suatu penyakit yang ditandai dengan suatu kondisi medik berupa hiperglikemia dimana terjadi peningkatan kadar glukosa dalam darah. DM adalah salah satu penyakit menahun yang sangat membutuhkan peran dokter, perawat, ahli gizi, tenaga kesehatan lain bahkan yang paling penting adalah perhatian khusus keluarga. $^{1,2}$ 
Vol 1 No 1 Desember 2019

Menurut International Diabetes Federation (IDF) pada tahun 2013, terdapat sekitar 382 juta orang menderita diabetes di dunia. Sedangkan pada tahun 2035 diperkirakan meningkat menjadi 592 juta orang, dimana sekitar 175 orang diantaranya belum terdiagnosis dan terancam untuk berkembang hingga berkomplikasi. ${ }^{3}$ Lebih dari 371 juta orang di dunia berumur 20-79 tahun memiliki diabetes. Menurut Dirjen P2PL Indonesia merupakan Negara urutan ke-7 dengan prevalensi diabetes tertinggi, di bawah China, India, USA, Brazil, Rusia dan Mexico. ${ }^{4}$

World Health Organization (WHO) tahun 2016 mencatat dari 285 juta populasi masyarakat Indonesia terdapat mortalitas penduduk Indonesia yang menderita diabetes meninggal di rentang usia 30-70 tahun. Persentase mortalitas akibat diabetes dari tahun 1980 semakin meningkat hingga tahun 2014. Pemeriksaan kadar glukosa darah merupakan salah satu pemeriksaan penunjang yang menjadi pemeriksaan utama di unit pelayanan primer serta pengobatan lini pertama yang sering diberikan pada unit pelayanan adalah metformin ataupun sulphonylurea. ${ }^{5}$ 3,7 juta kematian di dunia, diantaranya 1,5 juta kematian disebabkan oleh diabetes. $^{6}$

Pada tahun 2007 dan 2013, Riset Kesehatan Dasar (Riskesdas) melakukan wawancara menghitung proporsi diabetes mellitus pada usia $\geq 15$ tahun. Hasil wawancara tersebut menunjukkan bahwa pada tahun 2013 proporsi diabetes mellitus yang meliputi daerah perkotaan meningkat dua kali lipat dibandingkan pada tahun 2007. Diabetes
Mellitus dapat menimbulkan dampak yang sangat buruk dengan seiringnya waktu tanpa ada perhatian khusus. Berdasarkan data presentase komplikasi diabetes mellitus di RSUP Dr. Cipto Mangunkusumo Jakarta (RSCM) sebanyak 54\% pasien yang dirawat tahun 2011 mengalami komplikasi neuropati lalu diikuti retinopati diabetik dan proteinuria. $^{3}$

Penelitian epidemiologi menunjukkan peningkatan prevalensi dan insidensi cenderung pada diabetes mellitus tipe 2., Diabetes tipe 2 di karakteristikkan dengan adanya sekresi insulin yang terganggu, resistensi insulin, produksi glukosa hati yang berlebihan, dan metabolisme lemak yang abnormal. ${ }^{7}$

Ada 4 pilar yang perlu di perhatikan dalam memberikan tatalaksana pada penderita diabetes, yaitu: edukasi, latihan jasmani, terapi gizi medis, dan intervensi farmakologi. Intervensi farmakologi pada penderita diabetes terbagi menjadi dua, yaitu: pemberian secara bentuk oral dan dalam bentuk suntikan. Obat hipoglikemik oral atau biasa disebut $\mathrm{OHO}$ yang sering digunakan di Indonesia antara lain: sulfonylurea, glinid (pemicu sekresi insulin), biguanid, tiazolidindion (peningkat sensitivitas insulin), metformin (penghambat glukoneogenesis), acarbose (penghambat glukosidase alfa). Obat suntikan terdiri dari beberapa jenis, yaitu: insulin kerja cepat, insulin kerja pendek, insulin kerja menengah, insulin kerja panjang, insulin campuran tetap. ${ }^{8}$

Salah satu obat hipoglikemik oral yang sering digunakan pada penderita diabetes 
Vol 1 No 1 Desember 2019

mellitus tipe 2 adalah metformin. Metformin selain bertujuan mengendalikan glikemik tetapi juga mengendalikan faktor kardiovaskuler dan dapat memperbaiki disfungsi endotel, hemostasis, stress oksidatif, resistensi insulin, profil lipid dan redistribusi lemak. ${ }^{8}$ Namun tetapi metformin memiliki efek samping seperti dispepsia, diare dan asidosis laktat, dengan penurunan HbA1c sekitar 1,0-2,0\%. Sulfonilurea dan glinid memiliki efek samping kenaikan berat badan serta hipoglikemia. Penghambat alfa glukosidase dapat menyebabkan flatulen serta tinja lembek. Tiazolidindion menyebabkan edema, penghambat SGLT-2 mengakibatkan dehidrasi dan infeksi saluran kemih. ${ }^{1}$

Pada beberapa kasus, penggunaan $\mathrm{OHO}$ perlu memperhatikan masalah gangguan faal hati dan pasien dengan gangguan hipoksemia. ${ }^{1}$ Maka dari itu beberapa penelitian terbaru menemukan pengobatan dengan efek samping minimal terhadap penderita diabetes melitus tipe 2 .

Oleh karena itu, penelitian ini dilakukan untuk mengetahui keterkendalian glikemik pada pemberian minyak jintan hitam terhadap kadar HbA1C (\%) pada pasien diabetes mellitus tipe 2 yang juga mengkonsumsi OHO.

Penelitian ini diharapkan dapat digunakan sebagai pertimbangan untuk terapi adjuvan terhadap keterkendalian glikemik pada pasien diabetes melitus tipe 2 .

\section{METODE}

Jenis penelitian ini bersifat eksperimental dengan rancangan pretest post test control group design bertujuan untuk melihat keterkendalian glikemik pada pasien diabetes mellitus tipe 2 .

Penelitian ini dilakukan di RSUD Deli Serdang yang terletak di jalan Thamrin Deli Serdang Indonesia. Metode penarikan sampel pada penelitian ini yaitu purposive sampling. Sampel penelitian ini adalah pasien diabetes melitus tipe 2 dengan rentang usia 30-69 tahun.

Data dalam penelitian ini didapat dari lembar persetujuan subjek dan hasil laboratorium. Data yang terkumpul didalam penelitian ini dilakukan uji normalitas menggunakan uji Shapiro-Wilk dan uji statistik menggunakan uji $\mathrm{t}$ berpasangan (paired samples $t$ test) dengan $\mathrm{P}$ value < 0.05 .

\section{HASIL}

Pemeriksaan kadar HbA1C (\%) pada kelompok kontrol mengalami penurunan yang signifikan $(\mathrm{P}$ value $=0,017)$ dibandingkan dengan kelompok standar. Tidak ada gejala efek samping selama penelitian berlangsung. 
Vol 1 No 1 Desember 2019

Tabel 1. Hasil uji t berpasangan (pasien yang diberikan perlakuan)

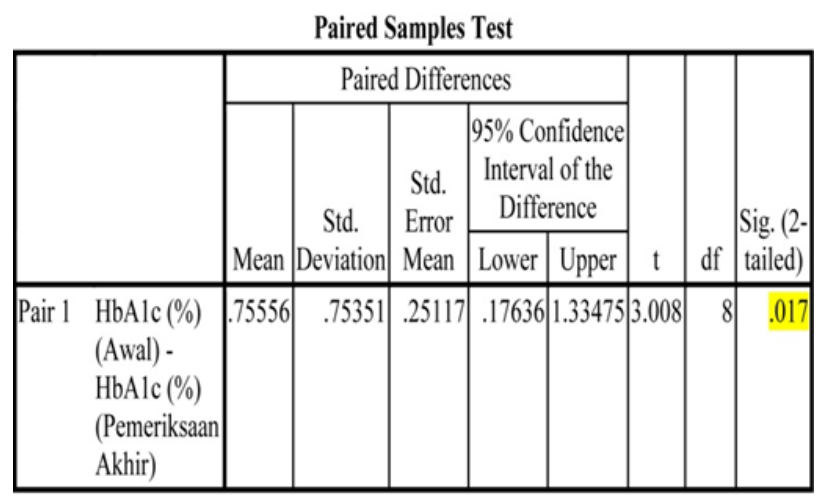

Pada data tabel 1 diperoleh nilai Sig 0,017 < tingkat signifikansi 0,05, maka disimpulkan bahwa terdapat perbedaan HbA1c (\%) yang signifikan antara awal dan pemeriksaan akhir.

Tabel 2. Hasil uji t berpasangan (pasien yang tidak diberikan perlakuan)

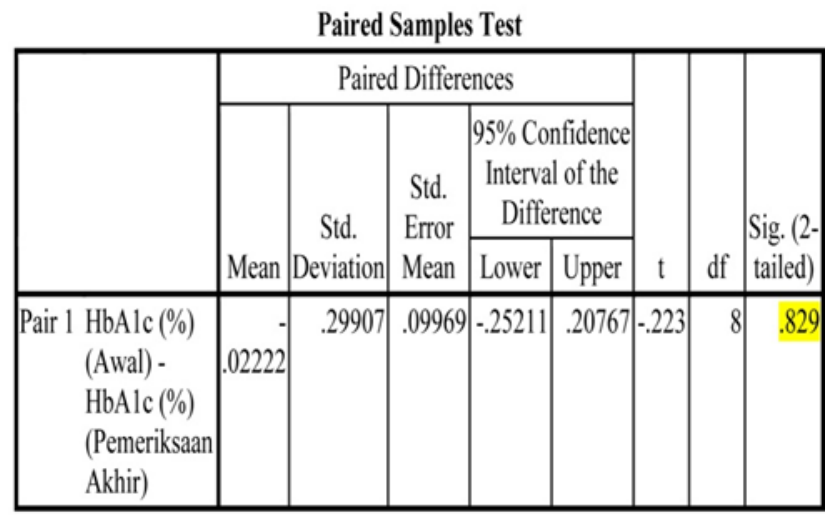

Pada data tabel 2 diperoleh nilai Sig 0,829> tingkat signifikansi 0,05, maka disimpulkan bahwa tidak terdapat perbedaan HbA1c (\%) yang signifikan antara awal dan pemeriksaan akhir.

\section{PEMBAHASAN}

Glikosilasi hemoglobin (HbA1C) adalah bentuk dari pemeriksaan hemoglobin yang dapat mengukur secara primer untuk mengidentifikasikan rata-rata jumlah konsentrasi glukosa plasma pada jangka waktu yang lama. Kadar glukosa yang normal membentuk jumlah hemoglobin terglikosilasi yang normal. Saat terjadi peningkatan sejumlah glukosa dalam plasma, maka saat itu pula terjadi peningkatan dari hemoglobin yang terglikosilasi dengan cara yang tidak dapat dijelaskan.

HbA1C sebagai penanda atau pemeriksaan untuk melihat rata-rata kadar glukosa plasma pada bulan sebelumnya. Dimana normal siklus hidup sel darah merah adalah 120 hari, maka pada saat itu molekul glukosa bereaksi dengan hemoglobin membentuk glikosilasi hemoglobin. ${ }^{9}$

Penelitian ini menggunakan minyak jintan hitam dan penggunaan obat hiperglikemi oral pada kelompok kontrol. Sebanyak 500mg minyak jintan hitam dikonsumsi sebanyak 1 kali sehari selama 8 minggu. Tidak terdapat keluhan efek samping setelah mengkonsumsi minyak jintan hitam.

Pengukuran HbA1C (\%) dilakukan sebelum dan sesudah perlakuan agar dapat melihat perubahan yang terjadi.

Jintan hitam secara signifikan mampu menurunkan kadar HbA1C (\%) pada kelompok kontrol dibandingkan dengan kelompok standar. Penurunan yang signifikan dari kadar HbA1C (\%) karenanya penggunaan jintan hitam dapat di sarankan 
Vol 1 No 1 Desember 2019

sebagai terapi tambahan pada pasien diabetes mellitus tipe 2 yang tidak dapat mengontrol keterkendalian glikemik hanya dengan menggunakan obat hiperglikemik oral.

Sebagaimana pada penelitian yang dilakukan oleh Kanter pada tahun 2004 mengenai kemungkinan efek protektif yang ditimbulkan oleh jintan hitam terhadap kerusakan sel beta akibat pemberian streptozotocin (STZ) sebagai induksi diabetes pada tikus. Ditemukan bahwa terapi menggunakan jintan hitam memiliki efek terapetik yang bersifat proteksi pada pasien diabetes dengan cara menurunkan stress oksidatif dan menjaga integritas dari sel beta pankreas. $^{10}$

Efek hipoglikemik dari jintan hitam pada penelitian Bamosa tahun 2010 diketahui kemungkinan terbesar dikarenakan adanya efek ganda yang mempengaruhi resistensi insulin dan fungsi dan sel beta sesuai dengan sumber yang jelas yaitu melalui perhitungan HOMA2. Dosis $2 \mathrm{mg}$ diberikan mampu menurunkan resistensi insulin $(\mathrm{P}<0.03)$ dan pada waktu yang sama dapat meningkatkan fungsi dari sel beta $(\mathrm{P}<0.02){ }^{11}$

\section{KESIMPULAN}

Jintan hitam dapat dijadikan terapi tambahan pada pasien diabetes mellitus tipe 2 yang tidak dapat mengontrol keterkendalian glikemiknya. Hal yang terpenting dari efek yang ditimbulkan oleh jintan hitam yaitu memiliki efek sensitasi insulin. Beberapa komponen yang mengambil peranan penting terhadap efek positif yang ditimbulkan yaitu thymoquinone, thymol, berbagai macam asam lemak yang tidak tersaturasi, lipase dan tannin.

Selain karena memiliki kandungan yang mengambil peranan mengapa jintan hitam dapat di sarankan menjadi terapi tambahan pada pasien diabetes melitus tipe 2 namun juga karena biayanya yang murah. Terdapat potensi cost benefit ratio yang dapat menjadi salah satu keuntungan yang menguntungkan.

\section{DAFTAR PUSTAKA}

1. PERKENI. Konsensus Pengendalian dan Pencegahan Diabetes Melitus Tipe 2 di Indonesia 2015. 2015:6-12.

2. PERKENI. Konsensus Pengelolaan dan Pencegahan Diabetes Melitus Tipe 2 di Indonesia. 2006;(DM):158.

3. Kemenkes RI. Situasi dan Analisis Diabetes. Pusat Data dan Informasi Kementerian Kesehatan RI.

4. Depkes RI. Diabetes Melitus Penyebab Kematian Nomor 6 di Dunia: Kemenkes Tawarkan Solusi CERDIK Melalui Posbind. 8 september. Published 2013.

5. World Health Organization. Diabetes Country Profile. 2016;48(6):18882A-18882B.

6. World Health Organization. Diabetes Fakta dan Angka. Published 2016.

7. Kasper, Fauci, Hauser, Longo, Jameson L. Harrison's Principles Of Internal Medicine. In: 19th ed. Mc Graw Hill Education; 2015:24042405. 
Vol 1 No 1 Desember 2019

8. Ndraha S. Diabetes Melitus Tipe 2

Dan Tatalaksana Terkini. Medicinus.

2014;27(2):9-16.

9. Shaafi SM, Kulkarni H. Effect of Kalonji ( $N$. Sativa) Seeds on Glycemic Control of Patients with Type-2 Diabetes. 2017;4(3):37-42.

10. Kanter Mehmet, Coskun Omer, Korkmaz Ahmet, Oter Sukru. Effects of Nigella sativa on Oxidative Stress and $\beta$-Cell Damage in Streptozotocin-Induced Diabetic Rats. 2004; 691:685-691.

11. Bamosa AO, Kaatabi H, Lebdaa FM, Elq A-M Al, Al-Sultanb A. Effect of Nigella sativa seeds on the glycemic control of patients with type 2 diabetes mellitus. Indian J Physiol Pharmacol. 2010;54(4):344-354. 